\title{
The use of photodynamic therapy in combined treatment of actinic keratosis
}

\author{
Wykorzystanie terapii fotodynamicznej w leczeniu skojarzonym rogowacenia \\ stonecznego
}

\author{
Katarzyna Małkińska', Joanna Bartosińska², Mirosław Kwaśny³, Dorota Krasowska ${ }^{4}$
}

\begin{abstract}
'Klinika Dermatologii, Wenerologii i Dermatologii Dziecięcej, Samodzielny Publiczny Szpital Kliniczny nr I w Lublinie, Polska ¿Zakład Kosmetologii i Medycyny Estetycznej, Uniwersytet Medyczny w Lublinie, Polska

${ }^{3}$ Instytut Optoelektroniki Wojskowej Akademii Technicznej im. Jarosława Dąbrowskiego w Warszawie, Polska

${ }^{4}$ Katedra i Klinika Dermatologii, Wenerologii i Dermatologii Dziecięcej, Uniwersytet Medyczny w Lublinie, Polska
\end{abstract}

'Dermatology, Venereology and Paediatric Dermatology Clinic, the Independent Clinical Hospital No. I (SPSK I) in Lublin, Poland 2Department of Cosmetology and Aesthetic Medicine, Medical University of Lublin, Poland

${ }^{3}$ Institute of Optoelectronic of the "Jarosław Dąbrowski" Military University of Technology in Warsaw, Poland

${ }^{4}$ Department of Dermatology, Venereology, and Paediatric Dermatology, Medical University of Lublin, Poland

Dermatol Rev/Przegl Dermatol 2020, 107, 534-545

DOI: https://doi.org/l 0.5 | |4/dr.2020.103889

\section{CORRESPONDING AUTHOR/ ADRES DO KORESPONDENCJI:} dr n. med. Katarzyna Małkińska Katedra i Klinika Dermatologii, Wenerologii i Dermatologii Dziecięcej

ul. Staszica 11

Uniwersytet Medyczny

20-08I Lublin, Polska

Phone: +48722363522

E-mail:

drmalkinska.katarzyna@gmail.com

\begin{abstract}
Actinic keratosis, a type of squamous cell carcinoma in situ, is characterised by hyperkeratotic focal lesions formed on the ultraviolet-damaged skin. Usually, there are a few to several so foci of actinic keratosis, and less often a single lesion is present. The treatment depends on the number, size, duration, and location of lesions. This study discusses some options of combined treatment of actinic keratosis and the possible risk of cancer associated with the use of photodynamic therapy in combination with laser therapy, topical medications (imiquimod, 5-fluorouracil, diclofenac, topical retinoids, ingenol mebutate, calcipotriol), and microneedling. Combined treatment is worth considering in cases of numerous hyperkeratotic foci, particularly in difficult-to-treat locations. Effective photoprotection is essential for all persons with actinic keratosis.
\end{abstract}

\section{STRESZCZENIE}

Rogowacenie słoneczne, odmiana raka kolczystokomórkowego in situ, charakteryzuje się występowaniem hiperkeratotycznych ognisk na podłożu skóry uszkodzonej promieniowaniem ultrafioletowym. Zwykle występuje kilka do kilkunastu ognisk rogowacenia słonecznego, rzadziej obecna jest pojedyncza zmiana chorobowa. Wybór sposobu leczenia zależy od liczby, wielkości, czasu trwania i lokalizacji wykwitów. W niniejszej pracy omówiono możliwości leczenia skojarzonego rogowacenia słonecznego oraz obszaru zagrożenia nowotworowego z wykorzystaniem terapii fotodynamicznej w połączeniu z laseroterapią, lekami miejscowymi (imikwimod, 5-fluorouracyl, diklofenak, retinoidy miejscowe, mebutynian ingenolu, kalcypotriol) oraz mikronakłuciami. Leczenie skojarzone warto rozważyć w przypadku licznych hiperkeratotycznych ognisk chorobowych, zwłaszcza w lokalizacjach trudno poddających się leczeniu. U wszystkich osób z rogowaceniem słonecznym konieczna jest skuteczna fotoprotekcja.

Key words: actinic keratosis, photodynamic therapy, combined treatment. Słowa kluczowe: rogowacenie słoneczne, terapia fotodynamiczna, leczenie skojarzone. 


\section{INTRODUCTION}

Actinic keratosis (AK) occurs in people all over the world, more often in people with skin phototypes I and II according to the Fitzpatrick classification, and also more often in men compared to women. It is characterised by the presence of hyperkeratotic foci on the surface of skin damaged by ultraviolet (UV) radiation. Usually, several to a dozen or so AK foci are observed, and a single focus is less common. AK can form on any skin surface chronically exposed to UV radiation, but it mostly affects the fronto-parietal area, nose, auricles, forearms, and backs of hands [1].

Actinic keratosis is a type of squamous cell carcinoma in situ (SCC), although the risk of a single lesion transforming into invasive SCC ranges from $0.1 \%$ to $20 \%$ [2]. Due to the clinical characteristics of red-pink spots and scaly patches, diagnosis is based on medical history and physical examination, which may be extended with dermoscopic evaluation. There are 3 clinical grades of AK according to Olsen [3], which correspond to individual dermoscopic patterns. Early lesions, AK grade I, are identified by palpation as small rough spots or patches that in dermoscopy correspond to a red pseudo-mesh pattern and discrete white scales. AK grade II (visible, palpable changes) in dermoscopy visible as an erythematous background with white or yellow hyperkeratotic plugs in the widened hair follicles (strawberry pattern). AK grade III is clinically present in the form of thick, hyperkeratotic foci of yellow or brown colour, in dermoscopy showing white-yellow non-structural areas [4].

Observations that AK may occur within entire areas of chronically sun-damaged skin have led to the concept of a "cancerisation field" or "cancer risk area". This term means that genetically altered keratinocyte clones, which tend to develop into neoplastic lesions, are present in clinically unchanged skin in the vicinity of tumour cells [4-6]. Due to the potential in situ progression of cancer into invasive SCC, AK foci should be diagnosed and treated as early as possible. The choice of treatment depends on the number, size, duration, and location of eruptions. In addition, patients' age and general health (immunosuppression, history of skin cancer), adherence and compliance to medical recommendations, and the expected cosmetic effect are also important. Avoiding exposure to UV radiation and sun protection (UV filter creams) are essential for the course of therapy, as it was shown that regular use of photoprotection reduced the number of clinically visible AK foci $[4,6]$. A protective effect of orally administered nicotinamide, which significantly decreased the incidence of non-melanoma skin cancer (NMSC) and AK foci in high-risk patients, was also reported $[7,8]$.

\section{WPROWADZENIE}

Rogowacenie słoneczne (actinic keratosis - AK) występuje u ludzi na całym świecie, częściej u osób z I oraz II fototypem skóry wg klasyfikacji Fitzpatricka oraz u mężczyzn. Charakteryzuje się obecnością hiperkeratotycznych ognisk na podłożu skóry uszkodzonej promieniowaniem ultrafioletowym (UV). Zwykle obserwuje się od kilku do kilkunastu ognisk AK, rzadziej występuje pojedyncze ognisko chorobowe. Rogowacenie słoneczne może powstać na każdej powierzchni skóry narażonej na przewlekłą ekspozycję na promieniowanie UV, ale zazwyczaj zajmuje okolicę czołowo-ciemieniową, nos, małżowiny uszne oraz przedramiona i grzbiety rąk [1].

Rogowacenie słoneczne jest odmianą raka kolczystokomórkowego (squamous cell carcinoma - SCC) in situ, jakkolwiek ryzyko przejścia pojedynczej zmiany chorobowej w inwazyjną postać SCC waha się od $0,1 \%$ do $20 \%$ [2]. Ze względu na charakterystyczne cechy kliniczne - czerwono-różowe plamy oraz tarczki pokryte łuską, diagnoza jest stawiana na podstawie wywiadu, badania fizykalnego oraz dodatkowo dermoskopowego. Według Olsen wyróżniono trzy stopnie kliniczne AK [3], którym odpowiadają wzory dermoskopowe. Wczesne zmiany - AK I stopnia, są rozpoznawane podczas badania palpacyjnego: występują małe szorstkie plamki lub plamy, którym w dermoskopii odpowiada wzór czerwonej pseudosiatki i dyskretne białe łuski. AK II stopnia (zmiany widoczne, wyczuwalne) - w badaniu dermoskopowym widoczne jest rumieniowe tło z białymi lub żółtymi hiperkeratotycznymi czopami w poszerzonych ujściach mieszków włosowych (wzór truskawki). AK III stopnia ma postać grubych, hiperkeratotycznych ognisk o zabarwieniu żółtym lub brązowym, w obrazie dermoskopowym dających obraz biało-żółtych obszarów bezstrukturalnych [4].

Zaobserwowano, że AK może występować w obrębie całych obszarów skóry przewlekle uszkodzonej na skutek działania promieni słonecznych, co przyczyniło się do powstania koncepcji „pola kanceryzacji” lub „obszaru zagrożenia nowotworowego”. Określenia te oznaczają, że w sąsiedztwie komórek nowotworowych, w klinicznie niezmienionej skórze, obecne są genetycznie zmienione klony keratynocytów, które wykazują tendencję do rozwoju zmian nowotworowych [4-6]. Z uwagi na potencjalną progresję raka in situ w inwazyjną postać SCC ogniska AK powinny być jak najwcześniej rozpoznawane i leczone. Wybór sposobu leczenia zależy od liczby, wielkości, czasu trwania i lokalizacji wykwitów. Ponadto ważny jest wiek i ogólny stan zdrowia pacjenta (immunosupresja, przebyte choroby nowotworowe skóry), jego gotowość do współpracy i stosowania się do zaleceń lekarskich (adherence i compliance) oraz spodziewany efekt kosme- 
Methods of treatment of AK associated with a low risk of SCC development, i.e. less than 5 foci in a given area, are as follows: cryotherapy/cryodestruction, laser therapy - especially carbon dioxide $\left(\mathrm{CO}_{2}\right)$ and erbium-yag (Er-YAG) lasers, curettage, and electrocoagulation [6]. Patients with a greater number of AK foci, with features of extensive photodamage to the skin or during immunosuppressive treatment are classified as being at high risk of invasive SCC development, and should be systematically monitored and qualified for therapies enabling treatment of the entire cancer risk area, including the following: photodynamic therapy (PDT), 5-fluorouracil (5-FU), diclofenac, imiquimod and ingenol mebutate [5-7].

\section{PHOTODYNAMIC THERAPY}

Photodynamic therapy depends on the presence of 3 factors: a photosensitising substance, a light source, and oxygen. A photosensitising substance is a molecule that penetrates into a target cell and is activated by light of an appropriate wavelength. Currently, the most commonly used photosensitiser is a-aminolevulinic acid (ALA) - a biological precursor of protoporphyrin IX (PpIX), or its methylated derivative - methyl aminolevulinate (MAL). The photosensitiser is applied to the skin and then taken up by cells. In pathologically changed keratinocytes, the photosensitising substance is accumulated to a much greater extent than in normal cells. Absorbing light of an appropriate wavelength leads to the formation of reactive oxygen species, including singlet oxygen. As a result, proteins, deoxyribonucleic acid (DNA), and phospholipids become permanently damaged, and also changes in microcirculation and local inflammatory reactions, and cell apoptosis occur. Damage to the surrounding healthy tissues can be minimised by modifying the selectivity of the uptake and an appropriate selection of the wavelength and duration of the therapy $[1,9,10]$. A limited penetration capacity of the photosensitiser is an important problem in the course of the therapy. In hyperkeratotic lesions, the depth of penetration of the photosensitiser is definitely reduced; therefore, it is necessary to add another method, aimed at removal of the stratum corneum [11]. In order to reduce keratosis, patients are advised to use topical retinoids. Treatment is more effective in the case of changes on the face and scalp than in acral areas [10]. Combined methods allow an increased effectiveness of treatment.

The main adverse effect of PDT is pain during the procedure, which makes patients less cooperative and less motivated to continue the treatment [11]. There is no significant difference between the efficacy of MAL and ALA treatments, although it has been shown that patients reported less pain when ALA tyczny. Podstawowe znaczenie w skuteczności terapii ma unikanie ekspozycji na promieniowanie UV oraz ochrona przeciwsłoneczna (kremy z filtrem UV). Wykazano, że regularne stosowanie fotoprotekcji wpływa na zmniejszenie liczby widocznych klinicznie ognisk AK $[4,6]$. Opisano również ochronny wpływ doustnie przyjmowanego nikotynamidu, który istotnie zmniejsza częstość występowania nowotworów skóry (non-melanoma skin cancer - NMSC) i ognisk AK u pacjentów z grupy wysokiego ryzyka [7, 8].

Wśród metod leczenia AK o niskim ryzyku rozwoju SCC, tzn. poniżej 5 ognisk w danej okolicy, wymienia się krioterapię/kriodestrukcję, laseroterapię - zwłaszcza lasery: dwutlenkowęglowy $\left(\mathrm{CO}_{2}\right)$ i erbowo-yagowy (Er-YAG), łyżeczkowanie i elektrokoagulację [6]. Chorzy z większą liczbą ognisk AK, z cechami rozległego fotouszkodzenia skóry lub w trakcie immunosupresji są zaliczani do grupy wysokiego ryzyka rozwoju inwazyjnego SCC i powinni być systematycznie monitorowani i kwalifikowani do terapii umożliwiających leczenie całego obszaru zagrożenia nowotworowego, do których należą: terapia fotodynamiczna (photodynamic therapy - PDT), 5-fluorouracyl (5-FU), diklofenak, imikwimod oraz mebutynian ingenolu [5-7].

\section{TERAPIA FOTODYNAMICZNA}

Terapia fotodynamiczna to metoda, której działanie jest uzależnione od obecności trzech czynników: substancji fotouczulającej, źródła światła i tlenu. Substancja fotouczulająca to cząsteczka, która penetruje do komórki docelowej i jest aktywowana przez światło o odpowiedniej długości fali. Obecnie jako fotouczulacz najczęściej wykorzystywany jest kwas a-aminolewulinowy (ALA) - biologiczny prekursor protoporfiryny IX (PpIX), lub jego metylowana pochodna - ester metyloaminolewulinowy (MAL). Fotouczulacz jest aplikowany na skórę, a następnie wychwytywany przez komórki. W patologicznie zmienionych keratynocytach substancja fotouczulająca kumulowana jest w znacznie większym stopniu niż w komórkach prawidłowych. Pochłanianie światła o odpowiedniej długości fali prowadzi do powstawania reaktywnych form tlenu, w tym tlenu singletowego. W efekcie dochodzi do trwałego uszkodzenia białek, kwasu dezoksyrybonukleinowego (DNA), fosfolipidów, a także do zmian w mikrokrążeniu oraz miejscowej reakcji zapalnej i apoptozy komórek. Uszkodzenie otaczających zdrowych tkanek można zminimalizować poprzez modyfikację selektywności wychwytu oraz odpowiedni dobór długości światła i czasu trwania terapii $[1,9,10]$. Istotnym problemem jest ograniczona zdolność penetracji fotouczulacza. W zmianach hiperkeratotycznych głębokość wnikania fotouczulacza jest zdecydowanie osłabiona, 
was used as a photosensitiser. MAL is believed to be more selective for precancerous cells than ALA [12]. On the other hand, introduction of the daylight PDT (dPDT) modification allows a reduction in the severity and frequency of adverse effects. Both ALA-PDT and MAL-PDT are recommended for the treatment of AK (in line with the 2019 European guidelines for local PDT - strength of recommendation A and quality of evidence I) $[10,13]$.

\section{OBJECTIVE}

The aim of the study is to review options for the treatment of actinic keratosis and the cancer risk area with the use of photodynamic therapy in combination with other therapeutic methods (combined treatment).

\section{COMBINED TREATMENT}

Combined treatment of AK consists of combining methods with different mechanisms of action, including surgery, cryosurgery, laser techniques, photodynamic therapy, and various topical preparations in order to improve its effectiveness [7, 14]. A combination of therapies focused on lesions and the cancer risk area is a recognised in the treatment of coexisting AK lesions of varying severity, including hyperkeratotic lesions or lesions affecting large areas of the skin. Another, less frequently used option is a combination of two different types of approaches to treatment of the cancer risk area [15]. In patients with mild and moderate AK foci (Olsen grades I and II), PDT gives very good therapeutic and cosmetic effects. Treatment is less effective in the case of hyperkeratotic changes (Olsen grade III) and in case of sub-total surgery. Accordingly, combining PDT with another surgical method or topical application of a medical formulation allows these limitations to be overcome and leads to effective treatment [15].

\section{Photodynamic therapy and ablative fractional laser combined therapy}

The combination of PDT with ablative fractional laser (AFXL) increases penetration of the photosensitiser and thus improves outcomes of the treatment. The concept of such a procedure, called a laser-assisted drug delivery, was first described in 1987. Initially, this method used an ablative $\mathrm{CO}_{2}$ laser. In 2004 the fractional photothermolysis method using focused laser rays causing formation of a grid of microscopic injuries leaving the surrounding skin intact, the socalled vertical microchannels, was introduced. Microchannels produced by AFXL facilitate penetration of the formula containing ALA or MAL, increasing ac- w związku z tym konieczne jest dołączenie innej metody, umożliwiającej usunięcie nawarstwień rogowych [11]. W celu zmniejszenia rogowacenia pacjentom zaleca się stosowanie miejscowych retinoidów. Leczenie jest bardziej skuteczne w przypadku zmian na twarzy i skórze głowy niż w okolicach akralnych [10]. Skuteczność terapii można zwiększyć poprzez zastosowanie metod skojarzonych.

Głównym działaniem niepożądanym PDT jest ból podczas zabiegu, który utrudnia współpracę z pacjentem i zmniejsza jego motywację do kontynuacji leczenia [11]. Nie ma istotnej różnicy między skutecznością zabiegu z użyciem MAL i ALA, ale wykazano, że po zastosowaniu jako fotouczulacza ALA pacjenci zgłaszali mniejsze dolegliwości bólowe. Uważa się, że MAL jest bardziej selektywny dla komórek przedrakowych niż ALA [12]. Z kolei wprowadzenie modyfikacji PDT polegającej na wykorzystaniu światła dziennego (daylight PDT - dPDT) pozwala na zmniejszenie nasilenia i częstotliwości występowania działań niepożądanych. Zarówno ALA-PDT, jak i MAL-PDT są rekomendowane w leczeniu AK (zgodnie z europejskimi wytycznymi z 2019 r. dotyczącymi miejscowego PDT - siła zaleceń A, jakość dowodów I) [10, 13].

\section{CEL PRACY}

Celem pracy jest przegląd możliwości leczenia rogowacenia słonecznego oraz obszaru zagrożenia nowotworowego z wykorzystaniem terapii fotodynamicznej w połączeniu $\mathrm{z}$ innymi metodami (leczenie skojarzone).

\section{LECZENIE SKOJARZONE}

Leczenie skojarzone AK polega na łączeniu metod o odmiennych mechanizmach działania w celu poprawy skuteczności: zabiegu chirurgicznego, kriochirurgii, technik laserowych, terapii fotodynamicznej oraz różnych preparatów miejscowych $[7,14]$. Połączenie terapii ukierunkowanej na zmiany i na obszar zagrożenia nowotworowego jest uznaną kombinacją w leczeniu współwystępowania AK o różnym stopniu nasilenia, w tym zmian hiperkeratotycznych lub zajmujących rozległe powierzchnie skóry. Inną, rzadziej stosowaną opcją jest połączenie dwóch różnych rodzajów terapii obszaru zagrożenia nowotworowego [15]. U pacjentów z ogniskami AK o łagodnym i średnim nasileniu (stopień I i II wg Olsen) PDT daje bardzo dobre efekty terapeutyczne i kosmetyczne. Mniejszą skuteczność leczenia uzyskuje się w przypadku zmian hiperkeratotycznych (stopień III wg Olsen) oraz w sytuacji przeprowadzenia niepełnego zabiegu. W związku z powyższym łączenie PDT z inną metodą zabiegową lub miejscową aplikacją preparatu 
cumulation of the photosensitiser in dysplastic cells. Currently, the most commonly used fractional lasers are the Er-YAG laser $(k=2940 \mathrm{~nm})$ and the $\mathrm{CO}_{2}$ laser $(k=10,600 \mathrm{~nm})[11,16]$.

A meta-analysis conducted by Steeb et al. [11] showed that PDT was more effective after previous use of a fractional laser. This is due not only to the facilitated accumulation of PpIX, but also to the direct cytotoxic effect of AFXL on target cells. Combined treatment with the $\mathrm{CO}_{2}$ laser did not increase pain [11]. A study by Togsverd-Bo et al. [17] and Helsing et al. [18] showed a significantly higher treatment success rate with the combination therapy in patients after organ transplants. Togsverd-Bo et al. [17] demonstrated that fractional laser-assisted dPDT was more effective and better tolerated in the treatment of AK foci. Therefore, in people after organ transplants, laser-assisted PDT should be preferred. Helsing et al. [18] compared PDT combined with a $\mathrm{CO}_{2}$ fractional laser and therapy using a $\mathrm{CO}_{2}$ fractional laser alone to remove AK foci that were difficult to treat. These authors demonstrated that the combined therapy was definitely more effective in the complete removal of lesions and reducing the thickness of AK foci $[11,16]$. Similarly, Steeb et al. [11] showed that PDT combined with ablation laser increased the chance of regression of lesions compared to PDT monotherapy, without a significant difference in the patient's perception of pain. PDT combined with laser therapy may be the treatment of choice in therapeutically difficult cases of AK, such as the presence of hyperkeratotic foci, lesions in acral areas, or AK lesions in organ transplant recipients [11].

\section{Photodynamic therapy and topical agents combined therapy}

Topical preparations used in the treatment of AK foci are 5\% fluorouracil cream, 3\% diclofenac gel, 5\% imiquimod cream, and $0.015 \%$ ingenol mebutate gel. It was shown that 12 months after the end of treatment of numerous AK foci (grade I-III) on the scalp, $5 \%$ fluorouracil was more effective than 5\% imiquimod, MAL-PDT, and 0.015\% ingenol mebutate [19]. The use of combined PDT treatment with topical preparations may be a good therapeutic option for patients with multiple AK foci and cancer risk areas [15]. Topical medications most often combined with PDT are 5-FU and imiquimod [15]. Combinations of PDT with diclofenac, topical retinoids, ingenol mebutate, and calcipotriol were reported less frequently.

\section{Photodynamic therapy and imiquimod combination therapy}

Imiquimod (5\% cream), an agonist of the Tolllike 7 receptor (TLR7) present on dendritic cells, umożliwia pokonanie tych ograniczeń i przeprowadzenie skutecznej terapii [15].

\section{Skojarzenie terapii fotodynamicznej z ablacyjnym laserem frakcyjnym}

Połączenie PDT z ablacyjnym laserem frakcyjnym (ablative fractional laser - AFXL) umożliwia zwiększenie penetracji fotouczulacza, a tym samym poprawę efektów leczenia. Koncepcja takiego postępowania, nazwana wspomaganym laserowo dostarczaniem leku (laser-assisted drug delivery), po raz pierwszy została opisana w 1987 r. Początkowo stosowano laser ablacyjny $\mathrm{CO}_{2}$, a od $2004 \mathrm{r}$. metodę fototermolizy frakcyjnej z wykorzystaniem skupionych promieni lasera wytwarzających siatkę mikroskopijnych obrażeń z pozostawieniem skóry otaczającej w stanie nienaruszonym, tzw. pionowe mikrokanaliki. Wytworzone przez AFXL mikrokanaliki ułatwiają wnikanie preparatu z ALA lub MAL, zwiększając kumulację fotouczulacza w komórkach dysplastycznych. Obecnie najczęściej wykorzystywane lasery frakcyjne to laser Er-YAG $(k=2940 \mathrm{~nm})$ oraz laser $\mathrm{CO}_{2}(k=10600 \mathrm{~nm})[11,16]$.

Metaanaliza przeprowadzona przez Steeb i wsp. [11] wykazała większą skuteczność PDT po wcześniejszym zastosowaniu lasera frakcyjnego. Wynika to nie tylko $\mathrm{z}$ łatwiejszego gromadzenia PpIX, ale również z bezpośredniego wpływu cytotoksycznego AFXL na komórki docelowe. Leczenie skojarzone z laserem $\mathrm{CO}_{2}$ nie zwiększało dolegliwości bólowych [11]. W badaniach przeprowadzonych przez Togsverd-Bo i wsp. [17] oraz Helsing i wsp. [18] u pacjentów po przeszczepach narządów wykazano znacznie wyższy odsetek powodzenia leczenia w przypadku zastosowania terapii łączonej. Togsverd-Bo i wsp. [17] wykazali, że dPDT wspomagana laserem frakcyjnym jest skuteczniejsza i lepiej tolerowana w leczeniu ognisk AK. W związku z tym u osób po przeszczepianiu narządów preferowana powinna być PDT wspomagana laserem. Helsing i wsp. [18] porównywali terapię PDT łączoną z laserem frakcyjnym $\mathrm{CO}_{2}$ oraz terapię z wykorzystaniem wyłącznie lasera frakcyjnego $\mathrm{CO}_{2}$ do usuwania ognisk AK trudno poddających się leczeniu u osób po przeszcepieniach narządów. Autorzy wykazali, że terapia łączona była zdecydowanie bardziej skuteczna w całkowitym usunięciu zmian oraz zmniejszaniu grubości ognisk AK $[11,16]$. Podobnie Steeb i wsp. [11] wykazali, że PDT skojarzona z laserem ablacyjnym zwiększa szansę ustąpienia zmian chorobowych w porównaniu z monoterapią PDT, bez znaczącej różnicy w odczuwaniu przez pacjenta dolegliwości bólowych. PDT skojarzona z laseroterapią może być leczeniem pierwszego wyboru w trudnych terapeutycznie przypadkach AK, takich jak obecność ognisk hiperkeratotycznych, zmiany w okolicach akralnych lub AK u biorców przeszczepów narządów [11]. 
macrophages, and monocytes, regulates the level of cytokines (interferon (IFN)- $\alpha$, IFN- $\gamma$, TNF- $\alpha$, and interleukin (IL)-2, $-6,-8$, and -12) and modifies the immune response. The drug stimulates the skin's innate immune system through transcription of various pro-inflammatory mediators and stimulates the acquired immunity through activation of Langerhans cells. Due to its antiviral, anti-tumour, and immunomodulatory properties, imiquimod is used to treat various skin conditions. In AK therapy, the preparation with $5 \%$ imiquimod was approved in the twice-weekly regimen for 16 weeks [20, 21].

The successive use of PDT followed by (about 4-8 weeks later) $5 \%$ imiquimod is well tolerated, highly effective, safe, and has a very good cosmetic effect. In a comparative, randomised pilot study, Serra-Guillén et al. [22] showed that combination therapy was better tolerated and provided greater treatment satisfaction than imiquimod alone. PDT with the sequential use of imiquimod seems to be the most effective in multiple AK foci or cancer risk areas located on the skin of the face and head [20]. Tanaka et al. [23] observed that monotherapy with imiquimod or PDT gave satisfactory results in most AK lesions. Combination therapy is more effective in more resistant cases, although it is associated with a higher incidence of adverse effects, such as erosions and crusts [23].

\section{Photodynamic therapy and 5-fluorouracil combination therapy}

5-fluorouracil is a pyrimidine analogue, a chemotherapeutic agent with antitumour activity, classified as an antimetabolite. The mechanism of its action is related to inhibition of thymidylate synthase and incorporation of 5-FU into RNA and DNA. As a topically administered drug, it is effective in treating numerous AK foci. It is easy to apply, although adverse effects include pain, itching, burning, erythema, inflammation, and erosions at the application site. Various concentrations (0.5-5\%) and galenical forms (cream and solution) of 5-FU preparations are available worldwide. The recommended application scheme is twice a day until an erosion occurs. Treatment usually lasts for 2-4 weeks [24].

Sequential application of 5-FU and PDT gives good therapeutic and cosmetic effects. The synergism of these 2 methods results, inter alia, from their action on various structural elements of the cell. While PDT induces a phototoxic reaction and triggers formation of reactive oxygen species mainly in the cytoplasm of the cell, 5-FU as a thymine analogue inhibits DNA synthesis in the nucleus of cancer cells. After entering the cell, 5-FU undergoes phosphorylation, ribosylation, and by binding with thymidylate synthetase inhibits thymidine synthesis in the nucleus. Absence of

\section{Skojarzenie terapii fotodynamicznej z aplikacją preparatów miejscowych}

Preparatami miejscowymi stosowanymi w leczeniu ognisk AK są fluorouracyl 5\% w kremie, diklofenak 3\% w żelu, imikwimod 5\% w kremie oraz mebutynian ingenolu 0,015\% w żelu. Wykazano, że 12 miesięcy po zakończeniu leczenia licznych ognisk AK (stopień I-III) na skórze głowy skuteczniejszy był fluorouracyl $5 \%$, w porównaniu $\mathrm{z}$ imikwimodem 5\%, MAL-PDT i mebutynianem ingenolu 0,015\% [19]. Stosowanie leczenia skojarzonego PDT z preparatami miejscowymi może stanowić dobrą opcję dla pacjentów z licznymi ogniskami AK i obszarem zagrożenia nowotworowego [15]. Leki miejscowe najczęściej łączone z PDT to 5-FU i imikwimod [15]. Rzadziej opisywano połączenie PDT z diklofenakiem, miejscowymi retinoidami, mebutynianem ingenolu i kalcypotriolem.

\section{Skojarzenie terapii fotodynamicznej z imikwimodem}

Imikwimod (5\% krem), agonista receptora Toll-like 7 (TLR7) obecnego na komórkach dendrytycznych, makrofagach i monocytach, reguluje poziom cytokin (interferon (IFN)- $\alpha$, IFN- $\gamma$, TNF- $\alpha$, interleukina (IL)-2, IL-6, IL-8 i IL-12) i modyfikuje odpowiedź immunologiczną. Lek pobudza w skórze wrodzony układ odpornościowy poprzez transkrypcję mediatorów prozapalnych oraz stymuluje odporność nabytą przez aktywację komórek Langerhansa. Ze względu na działanie przeciwwirusowe, przeciwnowotworowe i immunomodulujące imikwimod jest stosowany w leczeniu chorób skóry. W terapii AK preparat z 5\% imikwimodem zatwierdzono w schemacie 2 razy w tygodniu przez 16 tygodni [20, 21].

Zastosowanie kolejno PDT, a następnie (po ok. 4-8 tygodniach) $5 \%$ imikwimodu jest dobrze tolerowane, charakteryzuje się wysoką skutecznością, bezpieczeństwem i bardzo dobrym efektem kosmetycznym. W porównawczym, randomizowanym badaniu pilotażowym Serra-Guillén i wsp. [22] wykazali, że terapia łączona jest lepiej tolerowana i pozwala uzyskać większą satysfakcję z leczenia niż aplikacja imikwimodu w monoterapii. PDT z sekwencyjnym zastosowaniem imikwimodu wydaje się najskuteczniejsza w przypadku licznych ognisk AK lub obszaru zagrożenia nowotworowego zlokalizowanych na skórze twarzy i głowy [20]. Tanaka i wsp. [23] zaobserwowali, że monoterapia z użyciem imikwimodu lub PDT daje satysfakcjonujące wyniki w większości zmian AK. W bardziej opornych przypadkach zastosowanie terapii łączonej jest skuteczniejsze, ale związane z częstszym występowaniem działań niepożądanych, takich jak nadżerki i strupy [23]. 
thymine leads to breakage of the DNA strand, which causes cell apoptosis. Thymine is crucial in AK and SCC because thymine and cytosine substitutions in certain regions of DNA in the p53 gene are the most common mutations. Hence, topical application of 5-FU results in a preferential elimination of AK [25]. A formula with 5-FU was used to induce inflammation and erythema of the skin to allow for a deeper penetration of the photosensitiser [15]. Nissen et al. [26] showed that the treatment of AK lesions located on the backs of the hands with the use of the combination of 5-FU and dPDT was more effective and did not cause more pain than the use of dPDT alone. The study completed by Pei et al. [25] also confirmed a greater efficacy and tolerability, and better cosmetic effects of sequential with 5-FU and ALA-PDT in comparison to ALA-PDT monotherapy.

\section{Photodynamic therapy and diclofenac combined therapy}

Actinic keratosis foci are characterised by increased expression of cyclooxygenase 2 (COX-2) - an enzyme involved in the synthesis of prostaglandins. In addition, prostaglandins are believed to increase the risk of developing UV-induced skin tumours. Consequently, diclofenac, a non-steroidal anti-inflammatory drug, is a good option for treating AK. It blocks the activity of cyclooxygenase and inhibits pro-inflammatory cytokines induced by UV radiation. Additionally, it blocks proliferation of tumour cells and angiogenesis, and induces metalloproteinases, increasing keratolytic processes and collagen degradation. Diclofenac is available as 3\% gel in $2.5 \%$ sodium hyaluronate. In practice, it is recommended that it be used daily for 60-90 days. The use of hyaluronic acid as a base ensures greater effectiveness of the therapy because it enables better penetration of the active substance through the epidermis and upper layers of the dermis. Diclofenac is fairly well tolerated, and its adverse effects include itching, erythema, dryness, and exfoliation. This drug should be avoided in people with hypersensitivity to acetylsalicylic acid [24].

The use of 3\% diclofenac gel for 4 weeks as a pretreatment before ALA-PDT was shown to have slightly better long-term effects (12-month follow-up) compared to the ALA-PDT monotherapy [27]. Cantisani et al. [28] compared the efficacy of daily MAL-PDT (MAL-dPDT) monotherapy with the sequential use of a $3 \%$ diclofenac formulation 30 days prior to the MAL-dPDT session. These authors showed that the sequential therapy caused lower inflammatory reaction than MAL-dPDT alone. Moreover, it allowed a reduction in the number of necessary MAL-dPDT sessions and, as a result, resulted in better cooperation with patients and improved quality of life [28].

\section{Skojarzenie terapii fotodynamicznej z 5-fluorouracylem}

5-fluorouracyl to analog pirymidyny, chemioterapeutyk o działaniu przeciwnowotworowym zaliczany do antymetabolitów. Mechanizm jego działania jest związany z hamowaniem syntazy tymidylanowej i włączeniem 5-FU do RNA i DNA. Jako lek podawany miejscowo jest skuteczny w leczeniu licznych ognisk AK. Jest łatwy w stosowaniu, działania niepożądane obejmują ból, świąd, pieczenie, rumień, stan zapalny i nadżerki w miejscu aplikacji. Na świecie dostępne są różne stężenia $(0,5-5 \%)$ i formy galenowe (krem i roztwór) preparatów z 5-FU. Zalecany schemat stosowania to aplikacja preparatu 2 razy dziennie do wystąpienia nadżerki. Leczenie zwykle trwa 2-4 tygodnie [24].

Sekwencyjne zastosowanie 5-FU i PDT daje dobre efekty terapeutyczne i kosmetyczne. Synergizm tych dwóch metod wynika między innymi z ich działania na różne elementy strukturalne komórki. Podczas gdy PDT indukuje reakcję fototoksyczną i powstawanie reaktywnych form tlenu głównie w cytoplazmie komórki, 5-FU jako analog tyminy hamuje syntezę DNA w jądrze komórek nowotworowych. Po wniknięciu do komórki 5-FU ulega fosforylacji, rybozylacji i wiążąc się z syntetazą tymidylanową, hamuje syntezę tymidyny w jądrze. Brak tyminy prowadzi do zerwania nici DNA, co powoduje apoptozę komórek. Tymina ma kluczowe znaczenie w AK i SCC, ponieważ substytucja tyminy i cytozyny w niektórych obszarach DNA w genie p53 należy do najczęstszych mutacji. Dlatego miejscowe stosowanie 5-FU powoduje preferencyjne wyeliminowanie AK [25]. Preparat z 5-FU był wykorzystywany do wywołania stanu zapalnego i rumienia skóry w celu umożliwienia głębszego wniknięcia fotouczulacza [15]. Nissen i wsp. [26] wykazali, że leczenie zmian AK zlokalizowanych na grzbietach rąk z zastosowaniem połączenia 5-FU z dPDT było skuteczniejsze i nie powodowało większych dolegliwości bólowych niż zastosowanie wyłącznie dPDT. Badania Pei i wsp. [25] również potwierdziły większą skuteczność, tolerancję i lepsze efekty kosmetyczne sekwencyjnego leczenia z wykorzystaniem 5-FU i ALA-PDT w porównaniu z monoterapią ALA-PDT.

\section{Skojarzenie terapii fotodynamicznej z diklofenakiem}

Ogniska AK charakteryzują się zwiększoną ekspresją cyklooksygenazy 2 (COX-2), enzymu uczestniczącego w syntezie prostaglandyn. Ponadto uważa się, że prostaglandyny zwiększają ryzyko rozwoju nowotworów skóry indukowanych przez UV. W związku z tym diklofenak, niesteroidowy lek przeciwzapalny, stanowi opcję w leczeniu AK. Blokuje on aktywność cyklooksygenazy i hamuje cytokiny prozapalne in- 


\section{Photodynamic therapy and topical retinoids combined therapy}

Topical retinoids have been used for over 30 years to treat skin conditions such as acne, melasma, psoriasis, photoaging, and AK. The most commonly used topical retinoids are: tretinoin, adapalene, isotretinoin, tazarotene, retinol (and its esters), and retinaldehyde. Adverse effects of topical retinoids include photosensitivity, erythema, erosions, itching, and soreness [12, 24].

The Galitzer study [29] assessed the safety and efficacy of treating AK lesions on backs of hands and forearms with $0.1 \%$ tazarotene gel twice daily for 1 week before ALA-PDT. The study confirmed a significant reduction in the number of AK foci after 8 weeks both in the group of people using tazarotene before ALA-PDT and in the group in which ALAPDT monotherapy was used (differences were not statistically significant). After the use of ALA-PDT monotherapy, reduction of AK lesions was so great that the addition of tazarotene did not cause any additional significant improvement. Immediately after the end of PDT, a greater severity of erythema was observed in the group of people taking tazarotene before ALA-PDT. However, based on the meta-analysis by Heppt et al. [15], it appears that pretreatment of AK lesions on the back of the hand and forearm with $0.1 \%$ tazarotene gel may increase the therapeutic effect of ALA-PDT without the risk of serious adverse effects.

\section{Photodynamic therapy and ingenol mebutate combined therapy}

Ingenol mebutate (IM) is a diterpene derived from a plant called Euphorbia peplus. Its mechanism of action is not fully understood, but in vivo and in vitro models suggest that it induces tumour cell death by damaging their plasma membrane and mitochondria, and stimulates neutrophil-mediated immune responses. For skin areas smaller than $25 \mathrm{~cm}^{2}$, the treatment must be applied for $2(0.015 \%$ formulation for lesions on the trunk or limbs) or 3 ( $0.05 \%$ formulation for lesions on the face or scalp) consecutive days. Treatment of larger areas is lengthy due to the need for an 8-week interval between treatment cycles. Reported adverse effects are erythema, swelling, exfoliation, crusts, pain, and superficial ulceration at the application site, subsiding 2 weeks after the end of treatment $[12,30]$.

Berman et al. [31] compared the efficacy and tolerability of treatment of facial AK foci with ALA-PDT therapy combined with IM for 3 consecutive days compared to each of these methods alone. ALA-PDT or IM monotherapy and combination therapy with the two were shown to be similarly effective. The dukowane przez promieniowanie UV. Dodatkowo blokuje proliferację komórek nowotworowych i angiogenezę oraz indukuje metaloproteinazy, powodując zwiększenie procesów keratolitycznych oraz degradacji kolagenu. Diklofenak jest dostępny w postaci 3\% żelu w 2,5\% hialuronianie sodu. W praktyce zaleca się jego codzienne stosowanie przez 60-90 dni. Wykorzystanie kwasu hialuronowego jako podłoża zapewnia większą skuteczność terapii, gdyż umożliwia lepsze przenikanie substancji aktywnej przez naskórek i górne warstwy skóry właściwej. Diklofenak jest dosyć dobrze tolerowany, objawy niepożądane obejmują świąd, rumień, suchość i złuszczanie. Powinno się unikać stosowania tego leku u osób z nadwrażliwością na kwas acetylosalicylowy [24].

Wykazano, że zastosowanie diklofenaku 3\% w żelu przez 4 tygodnie w leczeniu wstępnym przed ALA-PDT dawało nieznacznie lepsze efekty długoterminowe (badanie kontrolne po 12 miesiącach) w porównaniu z ALA-PDT w monoterapii [27]. Cantisani i wsp. [28] porównali skuteczność codziennej MAL-PDT (MAL-dPDT) w monoterapii z sekwencyjnym zastosowaniem preparatu z diklofenakiem 3\%przez 30 dni przed sesją MAL-dPDT. Autorzy wykazali, że terapia sekwencyjna dawała mniejszy odczyn zapalny niż MAL-dPDT w monoterapii. Ponadto pozwalała zmniejszyć liczbę koniecznych sesji MAL-dPDT i w efekcie powodowała lepszą współpracę pacjenta oraz poprawę jakości życia [28].

\section{Skojarzenie terapii fotodynamicznej z retinoidami miejscowymi}

Miejscowe retinoidy są stosowane od ponad 30 lat w leczeniu chorób skóry, takich jak trądzik, melasma, łuszczyca, fotostarzenie i AK. Najczęściej stosowanymi miejscowymi retinoidami są tretynoina, adaptalen, izotretynoina, tazaroten, retinol (i jego estry) oraz retinaldehyd. Objawy niepożądane po zastosowaniu miejscowych retinoidów obejmują fotonadwrażliwość, rumień, nadżerki, świąd i bolesność [12, 24].

W badaniu Galitzera [29] oceniano bezpieczeństwo i skuteczność leczenia ognisk AK na grzbietach rąk i przedramion $\mathrm{z}$ wykorzystaniem $0,1 \%$ tazarotenu w żelu 2 razy dziennie przez 1 tydzień przed ALA-PDT. Badania potwierdzily znaczne zmniejszenie liczby ognisk AK po 8 tygodniach zarówno w grupie osób stosujących tazaroten przed ALA-PDT, jak i w grupie, w której zastosowano monoterapię ALA-PDT (różnice nie były istotne statystycznie). Po zastosowaniu monoterapii ALA-PDT redukcja zmian AK była na tyle duża, że dołączenie tazarotenu nie spowodowało znaczącej poprawy. Bezpośrednio po zakończeniu PDT obserwowano większe nasilenie rumienia w grupie osób stosujących tazaroten przed ALA-PDT. Na podstawie metaanalizy przeprowadzonej przez Heppt i wsp. [15] wydaje się, że 
fewest adverse effects were observed after ALA-PDT monotherapy [31]. As skin cancer was found to be more common in the area treated with IM compared to imiquimod, early in 2020 the European Medicines Agency (EMA) recommended that IM should be discontinued. Results of clinical trials concerning the use of ingenol mebutate ester - ingenol disoxate, which showed a higher incidence of skin cancer than in the control group (7.7 vs. $2.9 \%$ ), are also important [30].

\section{Photodynamic therapy and calcipotriol combination therapy}

Vitamin $\mathrm{D}_{3}$ analogues bind specifically to vitamin D receptors expressed on keratinocytes, melanocytes, and various inflammatory cells. Vitamin $\mathrm{D}_{3}$ analogues regulate proliferation and differentiation of keratinocytes. Their anti-inflammatory effect by inhibiting cytotoxic T cells and NK cells and reducing the level of inflammatory cytokines was also confirmed. Calcipotriol, a synthetic topical vitamin $\mathrm{D}$ derivative, is widely used in psoriasis and has been reported to be effective in treating other diseases such as localised scleroderma, vitiligo, and ichthyosis. Topical vitamin D analogues are well tolerated; nevertheless, irritation and exfoliation are common adverse effects after long-term use. Hypercalcaemia and hyperuricaemia are rarely observed in people using the preparation in the amount of more than $100 \mathrm{~g}$ of calcipotriol per week [32]. The exact mechanism of action of PDT assisted by topical vitamin D analogues is still unknown. A higher level of MAL absorption following the use of calcipotriol may be partly explained by its enhancing effect on cell differentiation. Thus, these cells may become more susceptible to PDT. Another possible mechanism of action of local calcipotriol is the induction of an anti-tumour immune response [33].

In a randomised, controlled clinical trial, Torezan et al. [33] compared the efficacy of a combination of MAL-PDT and calcipotriol ointment (used at the dose of $0.05 \mathrm{mg} / \mathrm{g}$ once daily for 15 days before PDT) with MAL-PDT monotherapy for AK foci on the scalp. In both groups, lesions curettage was performed prior to the treatment. It was shown that in the case of grade I AK foci the effectiveness of both methods was comparable, while the combined treatment was more effective with regard to grade II lesions. Combination treatment was associated with more severe pain and more frequent occurrences of other adverse events (erythema, oedema, crusts) compared to PDT alone. These authors found a greater intensity of PpIX fluorescence before PDT irradiation at sites of previous calcipotriol application. Hence, more intense pain in the places where calcipotriol was applied could result from increased cellular accumulation of PpIX. Due to the higher effectiveness of treatment of grade II wstępne leczenie zmian AK na grzbiecie ręki i przedramieniu tazarotenem $0,1 \% \mathrm{w}$ żelu może zwiększać działanie terapeutyczne ALA-PDT bez ryzyka poważnych działań niepożądanych

\section{Skojarzenie terapii fotodynamicznej z mebutynianem ingenolu}

Mebutynian ingenolu (ingenol mebutate - IM) jest diterpenem pochodzącym z rośliny o nazwie Euphorbia peplus. Mechanizm jego działania nie jest w pełni poznany, ale modele in vivo i in vitro sugerują, że polega on na wywoływaniu śmierci komórek nowotworowych przez uszkodzenie ich błony plazmatycznej i mitochondriów oraz stymulacji odpowiedzi immunologicznej mediowanej przez neutrofile. W przypadku zajęcia obszarów skóry o powierzchni poniżej $25 \mathrm{~cm}^{2}$ leczenie musi być stosowane przez dwa kolejne dni (preparat o stężeniu 0,015\% dla zmian na tułowiu lub kończynach) lub trzy kolejne dni (preparat o stężeniu 0,05\% dla zmian na twarzy lub skórze głowy). Leczenie większych obszarów jest długotrwałe ze względu na konieczność 8-tygodniowej przerwy pomiędzy każdym cyklem leczenia. Opisywane objawy niepożądane to rumień, obrzęk, złuszczanie, strupy, ból oraz powierzchowne owrzodzenie w miejscu aplikacji, ustępujące po 2 tygodniach od zakończenia leczenia $[12,30]$.

Berman i wsp. [31] porównali skuteczność i tolerancję leczenia ognisk AK na twarzy terapią łączoną ALA-PDT z IM przez 3 kolejne dni w porównaniu z każdą z tych metod w monoterapii. Wykazano, że monoterapia ALA-PDT lub IM oraz leczenie skojarzone mają podobną skuteczność. Najmniej działań niepożądanych obserwowano po ALA-PDT w monoterapii [31]. W związku ze stwierdzonym częstszym występowaniem raka skóry na obszarze leczonym IM w porównaniu z imikwimodem Europejska Agencja Leków (EMA) zaleciła na początku 2020 r. zaprzestanie stosowania IM. Istotne są także wyniki badań klinicznych dotyczących estru mebutynianu ingenolu - disoksatemu ingenolu, w których wykazano większą częstość występowania nowotworów skóry niż w grupie kontrolnej (7,7 vs 2,9\%) [30].

\section{Skojarzenie terapii fotodynamicznej z kalcypotriolem}

Analogi witaminy $\mathrm{D}_{3}$ specyficznie wiążą się z receptorami witaminy D wykazującymi ekspresję na keratynocytach, melanocytach i komórkach zapalnych. Analogi witaminy $\mathrm{D}_{3}$ regulują proliferację i różnicowanie keratynocytów. Potwierdzono również ich działanie przeciwzapalne wynikające $\mathrm{z}$ hamowania cytotoksycznych komórek T i komórek NK oraz obniżenia poziomu cytokin zapalnych. Kalcypotriol, syntetyczna miejscowa pochodna witaminy D, jest stosowany w łuszczycy. Opisano również jego skuteczność 
lesions than grade I lesions, the authors suggest the need to investigate the effectiveness of the combination of calcipotriol and PDT in the treatment of grade III AK foci [33].

\section{Photodynamic therapy and microneedling combined therapy}

Microneedling (MN) pretreatment is another approach to increase the effectiveness of PDT and topical medications. MN can be obtained by means of a series of small needles on a roll or a mechanical punch that pierces superficial layers of the epidermis, resulting in increased delivery of the photosensitiser to dysplastic cells. A combination of MN and PDT was initially developed to shorten the incubation time of the photosensitiser and increase the effectiveness of PDT by facilitating drug delivery through microchannels. Several randomised clinical trials have compared the efficacy and adverse effects of microneedling-assisted PDT versus PDT alone. Results suggest that pretreatment with MN could increase the efficacy of PDT, especially in treatment-resistant lesions. However, it seems necessary to establish standards for the MN procedure used before PDT in clinical practice [14].

\section{CONCLUSIONS}

There are many effective procedures targeting single AK lesions and a cancer risk area. Therefore, a sequential combination of different methods further increases the number of possible therapeutic options. Various approaches to the treatment of AK result from absence of standards regarding the frequency of surgical therapies, such as cryosurgery, curettage, or laser therapy. Moreover, it is difficult to assess which combination of treatments is the most effective, although making use of synergistic effects of methods targeting individual AK lesions and the cancerisation field may be helpful in the treatment of extensive, hyperkeratotic AK foci. It should be remembered, however, that most therapeutic methods used in monotherapy are effective at removing a high percentage of AK foci, especially in the case of grade I lesions that have not been previously treated [14]. Combining PDT with other methods seems to be appropriate in cases of numerous hyperkeratotic AK foci, particularly in difficult-to-treat locations. All people with AK foci should be recommended an effective photoprotection using filters with a high SPF index and wearing protective clothing.

\section{CONFLICT OF INTEREST}

The authors declare no conflict of interest. w leczeniu innych chorób: twardziny ograniczonej, bielactwa i rybiej łuski. Miejscowe analogi witaminy D są dobrze tolerowane, jednak częstymi działaniami niepożądanymi po długotrwałym stosowaniu są podrażnienie i złuszczanie. Rzadko obserwuje się hiperkalcemię i hiperurykemię u osób stosujących preparat w ilości powyżej $100 \mathrm{~g}$ kalcypotriolu na tydzień [32]. Dokładny mechanizm działania PDT wspomaganego miejscowymi analogami witaminy D wciąż pozostaje nieznany. Wyższy poziom absorpcji MAL po zastosowaniu kalcypotriolu można częściowo wyjaśnić jego wpływem na zwiększenie różnicowania komórek. Komórki te mogą zatem stać się bardziej podatne na działanie PDT. Innym możliwym mechanizmem działania miejscowego kalcypotriolu jest indukcja przeciwnowotworowej odpowiedzi immunologicznej [33].

$\mathrm{W}$ randomizowanym, kontrolowanym badaniu klinicznym Torezan i wsp. [33] porównali skuteczność połączenia MAL-PDT z kalcypotriolem w maści (stosowanym w dawce 0,05 $\mathrm{mg} / \mathrm{g}$ raz dziennie przez 15 dni przed PDT) z MAL-PDT w monoterapii na ogniska AK na skórze głowy. W obu grupach przed rozpoczęciem leczenia wykonano zabieg łyżeczkowania zmian. Wykazano, że w przypadku ognisk AK I stopnia skuteczność obu metod była porównywalna, natomiast $\mathrm{w}$ odniesieniu do zmian stopnia II leczenie skojarzone było bardziej skuteczne. Leczenie skojarzone wiązało się z bardziej nasilonymi dolegliwościami bólowymi i częstszym występowaniem innych objawów niepożądanych (rumień, obrzęk, strupy) w porównaniu z PDT w monoterapii. Autorzy stwierdzili większe nasilenie fluorescencji PpIX przed naświetlaniami PDT w miejscach wcześniejszego zastosowania kalcypotriolu. Bardziej nasilone dolegliwości bólowe w miejscach, gdzie zastosowano kalcypotriol, moga zatem wynikać ze zwiększonej akumulacji PpIX w komórkach. Z uwagi na wyższą skuteczność leczenia zmian II niż I stopnia autorzy sugerują potrzebę zbadania skuteczności połączenia kalcypotriolu z PDT w leczeniu ognisk AK III stopnia [33].

\section{Skojarzenie terapii fotodynamicznej z mikronakłuciami}

Wstępne leczenie za pomocą mikronakłuć (microneedling) zwiększa skuteczność PDT i leków miejscowych. Mikronakłucia można uzyskać za pomocą działania wielu małych igieł na rolce lub stemplu mechanicznym, które przebijają powierzchowne warstwy naskórka, umożliwiając zwiększone dostarczanie fotouczulacza do komórek dysplastycznych. Początkowo opracowano połączenie mikronakłuć z PDT, aby skrócić czas inkubacji fotouczulacza i zwiększyć skuteczność PDT poprzez ułatwienie dostarczania leku przez mikrokanaliki. W kilku randomizowanych badaniach klinicznych porównano skuteczność i działania niepożądane PDT wspoma- 
ganej mikronakłuciami z PDT w monoterapii. Wyniki sugerują, że wstępne leczenie mikronakłuciami może zwiększyć skuteczność PDT, szczególnie w przypadkach zmian opornych na leczenie. Konieczne wydaje się jednak ustalenie standardów w zakresie procedury mikronakłuć stosowanej przed PDT w praktyce klinicznej [14].

\section{WNIOSKI}

Istnieje wiele skutecznych procedur ukierunkowanych na pojedyncze zmiany AK oraz na obszar zagrożenia nowotworowego. Sekwencyjne łączenie różnych metod dodatkowo zwiększa liczbę możliwych opcji terapeutycznych. Ponadto trudno jest ocenić, które leczenie skojarzone jest najbardziej skuteczne, ale wykorzystanie synergistycznego działania metod ukierunkowanych na poszczególne zmiany AK oraz na pole kanceryzacji może być pomocne w przypadku leczenia rozległych, hiperkeratotycznych ognisk AK. Należy jednak pamiętać, że większość metod stosowanych w monoterapii jest skuteczna w usuwaniu wysokiego odsetka ognisk AK, szczególnie w przypadku zmian I stopnia, które nie były wcześniej leczone [14]. Połączenie PDT z innymi metodami wydaje się słuszne w przypadku licznych, hiperkeratotycznych ognisk AK, zwłaszcza w lokalizacjach trudno poddających się leczeniu. U wszystkich osób z ogniskami AK należy zalecić skuteczną fotoprotekcję z wykorzystaniem filtrów o wysokim wskaźniku SPF oraz odzieży ochronnej.

\section{KONFLIKT INTERESÓW}

Autorzy nie zgłaszają konfliktu interesów.

\section{References}

\section{Piśmiennictwo}

1. Bartosińska J., Gerkowicz A., Niewiedzioł M., Szczepanik-Kułak P., Kwaśny M., Krasowska D.: Application of photodynamic therapy with the use of superluminescent light-emitting diode (sLED) lamp in actinic keratosis. Przegl Dermatol/ Dermatol Rev 2019, 106, 372-383.

2. Zalaudek I., Giacomel J., Schmid K., Bondino S., Rosendahl C., Cavicchini S., et al.: Dermatoscopy of facial actinic keratosis, intraepidermal carcinoma, and invasive squamous cell carcinoma: a progression model. J Am Acad Dermatol 2012, 66, 589-597.

3. Olsen E.A., Abernethy M.L., Kulp-Shorten C., Callen J.P., Glazer S.D., Huntley A., et al.: A double-blind, vehicle-controlled study evaluating masoprocol cream in the treatment of actinic keratoses on the head and neck. J Am Acad Dermatol 1991, 24, 738-743.

4. Zalaudek I., Piana S., Moscarella E., Longo C., Zendri E., Castagnetti F., et al.: Morphologic grading and treatment of facial actinic keratosis. Clin Dermatol 2014, 32, 80-87.

5. Torezan L.A., Festa-Neto C.: Cutaneous field cancerization: clinical, histopathological and therapeutic aspects. An Bras Dermatol 2013, 88, 775-786.

6. Włodarkiewicz A., Narbutt J., Adamski Z., Chodorowska G., Kaszuba A., Reich A., et al.: Rogowacenie słoneczne - aktualny stan wiedzy. Stanowisko ekspertów Polskiego Towarzystwa Dermatologicznego. Przegl Dermatol 2014, 101, 156-167.

7. Arenberger P., Arenbergerova M.: New and current preventive treatment options in actinic keratosis. J Eur Acad Dermatol Venereol 2017, 31, 13-17.

8. Chen A.C., Martin A.J., Choy B., Fernández-Peñas P., Dalziell R.A., McKenzie C.A., et al: A phase 3 randomized trial of nicotinamide for skin-cancer chemoprevention. N Engl J Med 2015 22, 1618-1626.

9. Wan M.T., Lin J.Y.: Current evidence and applications of photodynamic therapy in dermatology. Clin Cosmet Investig Dermatol 2014, 21, 145-163. 
10. Tampa M., Sarbu M.I., Matei C., Mitran C.I., Mitran M.I., Caruntu C.: Photodynamic therapy: a hot topic in dermato-oncology. Oncol Lett 2019, 17, 4085-4093.

11. Steeb T., Schlager J.G., Kohl C., Ruzicka T., Heppt M.V., Berking C.: Laser-assisted photodynamic therapy for actinic keratosis: A systematic review and meta-analysis. J Am Acad Dermatol 2019, 80, 947-956.

12. de Oliveira E.C.V., da Motta V.R.V., Pantoja P.C., Ilha C.S.O., Magalhães R.F., Galadari H., et al.: Actinic keratosis - review for clinical practice. Int J Dermatol 2019, 58, 400-407.

13. Morton C.A., Szeimies R.M., Basset-Seguin N., Calzavara-Pinton P., Gilaberte Y., Haedersdal M., et al.: European Dermatology Forum Guidelines on topical photodynamic therapy 2019 Part 1: treatment delivery and established indications - actinic keratoses, Bowen's disease and basal cell carcinomas. J Eur Acad Dermatol Venereol 2019, 33, $2225-2238$.

14. Steeb T., Wessely A., Leiter U., French L.E., Berking C., Heppt M.V.: The more the better? An appraisal of combination therapies for actinic keratosis. J Eur Acad Dermatol Venereol 2020, 34, 727-732.

15. Heppt M.V., Steeb T., Leiter U., Berking C.: Efficacy of photodynamic therapy combined with topical interventions for the treatment of actinic keratosis: a meta-analysis. J Eur Acad Dermatol Venereol 2019, 33, 863-873.

16. Vrani F., Sotiriou E., Lazaridou E., Vakirlis E., Sideris N., Kirmanidou E., et al.: Short incubation fractional CO2 laser-assisted photodynamic therapy vs. conventional photodynamic therapy in field-cancerized skin: 12-month follow-up results of a randomized intraindividual comparison study. J Eur Acad Dermatol Venereol 2019, 33, 79-83.

17. Togsverd-Bo K., Lei U., Erlendsson A.M., Taudorf E.H., Philipsen P.A., Wulf H.C., et al.: Combination of ablative fractional laser and daylight-mediated photodynamic therapy for actinic keratosis in organ transplant recipients - a randomized controlled trial. Br J Dermatol 2015, 172, 467-474.

18. Helsing P., Togsverd-Bo K., Veierod M.B., Mork G., Haedersdal M.: Intensified fractional CO2 laser-assisted photodynamic therapy vs. Laser alone for organ transplant recipients with multiple actinic keratoses and wart-like lesions: a randomized half-side comparative trial on dorsal hands. Br J Dermatol 2013, 169, 1087-1092.

19. Jansen M.H.E., Kessels J.P.H.M., Nelemans P.J., Kouloubis N., Arits A.H.M.M., van Pelt H.P.A., et al.: Randomized trial of four treatment approaches for actinic keratosis. N Engl J Med 2019, 7, 935-946.

20. Held L., Eigentler T.K., Leiter U., Garbe C., Berneburg M.J.: Effective combination of photodynamic therapy and imiquimod $5 \%$ cream in the treatment of actinic keratoses: three cases. Biomed Res Int 2013, 102698.

21. Bhatta A.K., Wang P., Keyal U., Zhao Z., Ji J., Zhu L.: Therapeutic effect of imiquimod enhanced ALA-PDT on cutaneous squamous cell carcinoma. Photodiagnosis Photodyn Ther 2018, 23, 273-280.

22. Serra-Guillén C., Nagore E., Hueso L., Traves V., Messeguer F., Sanmartín O., et al.: A randomized pilot comparative study of topical methyl aminolevulinate photodynamic therapy versus imiquimod $5 \%$ versus sequential application of both therapies in immunocompetent patients with actinic keratosis: clinical and histologic outcomes. J Am Acad Dermatol 2012, 66, e131-137.

23. Tanaka N., Ohata C., Ishii N., Imamura K., Ueda A., Furumura M., et al.: Comparative study for the effect of photodynamic therapy, imiquimod immunotherapy and combination of both therapies on 40 lesions of actinic keratosis in Japanese patients. J Dermatol 2013, 40, 962-967.

24. Dianzani C., Conforti C., Giuffrida R., Corneli P., di Meo N., Farinazzo E., et al.: Current therapies for actinic keratosis. Int J Dermatol 2020, 59, 677-684.

25. Pei S., Kaminska E.C.N., Tsoukas M.M.: Treatment of actinic keratoses: a randomized split-site approach comparison of sequential 5-fluorouracil and 5-aminolevulinic acid photodynamic therapy to 5-aminolevulinic acid photodynamic monotherapy. Dermatol Surg 2017, 43, 1170-1175.

26. Nissen C.V., Heerfordt I.M., Wiegell S.R., Mikkelsen C.S., Wulf H.C.: Pretreatment with 5-fluorouracil cream enhances the efficacy of daylight-mediated photodynamic therapy for actinic keratosis. Acta Derm Venereol 2017, 97, 617-621.

27. Van der Geer S., Krekels G.A.: Treatment of actinic keratoses on the dorsum of the hands: ALA-PDT versus diclofenac $3 \%$ gel followed by ALA-PDT. A placebo-controlled, double-blind, pilot study. J Dermatolog Treat 2009, 20, 259-265.

28. Cantisani C., Paolino G., Scarnò M., Didona D., Tallarico M., Moliterni E., et al.: Sequential methyl-aminolevulinate daylight photodynamic therapy and diclofenac plus hyaluronic acid gel treatment for multiple actinic keratosis evaluation. Dermatol Ther 2018, 31, e12710.

29. Galitzer B.I.: Effect of retinoid pretreatment on outcomes of patients treated by photodynamic therapy for actinic keratosis of the hand and forearm. J Drugs Dermatol 2011, 10, 1124-1132.

30. Cramer P., Stockfleth E.: Actinic keratosis: where do we stand and where is the future going to take us? Expert Opin Emerg Drugs 2020, 20, 1-10.

31. Berman B., Nestor M.S., Newburger J., Park H., Swenson N.: Treatment of facial actinic keratoses with aminolevulinic acid photodynamic therapy (ALA-PDT) or ingenol mebutate $0.015 \%$ gel with and without prior treatment with ALA-PDT. J Drugs Dermatol 2014, 13, 1353-1356.

32. Juntongjin P., Pongprasert R.: Calcipotriol ointment shows comparable efficacy to topical steroids in chronic hand eczema. Dermatol Ther 2019, 32, e12956.

33. Torezan L., Grinblat B., Haedersdal M., Valente N., Festa-Neto C., Szeimies R.M.: A randomized split-scalp study comparing calcipotriol-assisted methyl aminolaevulinate photodynamic therapy (MAL-PDT) with conventional MAL-PDT for the treatment of actinic keratosis. Br J Dermatol 2018, 179, 829-835.

Received: 24.06 .2020

Accepted: 4.10.2020

Otrzymano: $24.06 .2020 \mathrm{r}$.

Zaakceptowano: $4.10 .2020 \mathrm{r}$.

How to cite this article

Małkińska K., Bartosińska J., Kwaśny M., Krasowska D.: The use of photodynamic therapy in combined treatment of actinic keratosis, Dermatol Rev/Przegl Dermatol 2020, 107, 534-545. DOI: https://doi.org/10.5114/dr.2020.103889 